\title{
Optimisation of an oak chips-grape mix maceration process. Influence of chip dose and maceration time
}

\author{
Belén Gordillo a , Berta Baca-Bocanegra ${ }^{a}$, Francisco J. Rodriguez-Pulído ${ }^{a}$, M. Lourdes González-Miret ${ }^{\mathrm{a}}$, \\ Ignacio García Estévez ${ }^{\mathrm{b}}$, Natalia Quijada-Morín ${ }^{\mathrm{b}}$, Francisco J. Heredia a , M. Teresa Escribano-Bailón ${ }^{\mathrm{b}, *}$ \\ a Food Colour \& Quality Laboratory, Department of Nutrition \& Food Science, Facultad de Farmacia, Universidad de Sevilla, 41012 Sevilla, Spain \\ ${ }^{\mathrm{b}}$ Grupo de Investigación en Polifenoles, Facultad de Farmacia, University of Salamanca, Salamanca, Spain
}

\section{A R T I C L E I N F O}

\section{Article history:}

Received 1 December 2015

Received in revised form 12 February 2016

Accepted 13 March 2016

Available online 14 March 2016

\section{Keywords:}

Oak chips-grape maceration

American oak chips

Syrah red wine

Warm climate

Colour stability

\begin{abstract}
A B S T R A C T
Oak chips-related phenolics are able to modify the composition of red wine and modulate the colour stability. In this study, the effect of two maceration techniques, traditional and oak chips-grape mix process, on the phenolic composition and colour of Syrah red wines from warm climate was studied. Two doses of oak chips ( 3 and $6 \mathrm{~g} / \mathrm{L}$ ) at two maceration times ( 5 and 10 days) during fermentation was considered. Changes on phenolic composition (HPLC-DAD-MS), copigmentation/polymerisation (spectrophotometry), and colour (Tristimulus and Differential Colorimetry) were assessed by multivariate statistical techniques. The addition of oak chips at shorter maceration times enhanced phenolic extraction, colour and its stabilisation in comparison to the traditional maceration. On contrast, increasing chip dose in extended maceration time resulted in wines with lighter and less stable colour. Results open the possibility of optimise alternative technological applications to traditional grape maceration for avoiding the common loss of colour of wines from warm climate.
\end{abstract}

(C) 2016 Elsevier Ltd. All rights reserved.

\section{Introduction}

Phenolic compounds are the main chemical substances responsible for the sensorial characteristics of wines such as colour, astringency and bitterness (Monagas, Bartolomé, \& GómezCordovés, 2005). Among them, colour is one of the most important attribute defining the quality of wines since it is the first characteristic perceived, and therefore, it influences the acceptability by consumers.

In traditional winemaking, anthocyanins and other phenolic compounds are extracted from grapes and diffused into the must and wine along the fermentative maceration process (BusseValverde, Gómez-Plaza, López-Roca, Gil-Muñoz, \& Bautista-Ortín, 2011). While anthocyanins are the pigment accounting directly for the colour of red wine, colourless phenolics such as benzoic or hydroxycinnamic acids, flavanols or flavonols are involved in the stabilization of anthocyanins through copigmentation and polymerisation reactions so, they plays also a key role in the colour stability over time (Boulton, 2001; Escribano-Bailón \& Santos-

\footnotetext{
* Corresponding author.

E-mail addresses: bgordillo@us.es (B. Gordillo), bbaca1@us.es (B. Baca-Bocanegra), rpulido@us.es (F.J. Rodriguez-Pulído), miret@us.es (M.L. González-Miret), igarest@ usal.es (I. García Estévez), nataliaquijada@usal.es (N. Quijada-Morín), heredia@us.es (F.J. Heredia), escriban@usal.es (M.T. Escribano-Bailón).
}

Buelga, 2012). Given the importance of phenolic compounds for wine colour, studying and controlling the processing factors that influence their extraction and content during the maceration and fermentation of grapes is one of the main objectives to produce quality wines, especially in terms of full body-structure and stable colour (Sacchi, Bisson, \& Adams, 2005). In these regard, different alternative maceration techniques have been developed to enhance the extraction of grape components responsible for the colour, resulting in wines with a different phenolic composition from those produced by traditional methods (Añón et al., 2014; Canals, Llaudy, Canals, \& Zamora, 2008; Darias-Martín, Carrillo, Díaz, \& Boulton, 2001; González-Neves, Gil, Barreiro, \& Favre, 2010; Gordillo et al., 2014; Ivanova et al., 2011; Pérez-Lamela et al., 2007; Soto Vázquez, Río Segade, \& Orriols Fernández, 2010).

In particular, the use of oak chips fragments during winemaking is an approved oenological practice (OIV, 2012) increasingly applied by oenologists worldwide. Oak chips fragments obtained from barrels are a natural source of phenolic compounds like benzoic and cinnamic acids, and ellagitanins (among others) that are able to modify the wine composition and its sensory perception (Tao, García, \& Sun, 2014). In most cases, oak chips fragments are applied after the fermentative stage of winemaking to accelerate the aging process artificially and to obtain wines with more complex structure in a short aging period (Del Barrio-Galán, 
Medel-Marabolí, \& Peña-Neira, 2015; Gómez García-Carpintero, Gómez Gallego, Sánchez-Palomo, \& González Viñas, 2012). Apart from their recognised implication in the aroma, astringency, and bitterness, oak chips-related phenolics can also influence the colour stability of wine by participating in copigmentation reactions with anthocyanins (Alañón et al., 2013); especially if used in the initial stages of vinification when the main mechanisms of colour stabilization occur. In fact, the simultaneous maceration of grapes with oak chips fragments from barrels (oak chips-grape mix maceration process) has been proved to be an interesting alternative to traditional maceration in red wines from warm climate, where colour fall is a typical problem (Gordillo et al., 2014). In that preliminary study, the colour stabilization was improved due to the combined protective effect of phenolics derived from grape and oak chips.

However, other authors have shown inconsistent effects of oak chips-related compounds among vineyards or even controversial depending on the conditions applied including the chip dose, oak chips origin, toasting degree or maceration time without improving the phenolic potential or sensorial characteristics of wines (González-Sáiz et al., 2014; Soto Vázquez et al., 2010; Zimman, Joslin, Lyon, Meier, \& Waterhouse, 2002). On the other hand, studies focused on the optimisation of the oak chips-grape mix maceration processes by modifying the maceration conditions are still scarce. Thus, the main objective of this work is to evaluate the impact of applying two proportion of oak chips ( 3 and $6 \mathrm{~g} / \mathrm{L}$ ) at two maceration times ( 5 and 10 days) during the fermentative maceration of young Syrah wine from warm climate, and compared the phenolic composition and colour characteristics with a traditionally macerated red wine.

\section{Material and methods}

\subsection{Winemaking}

Red wines were made from grapes Vitis vinifera var. Syrah grown in "Condado de Huelva" Designation of Origin (DO), in the southwest of Spain (warm climate). About $2700 \mathrm{~kg}$ of grapes were harvested in 2014 vintage at optimum technological maturity (density of $1.100 \mathrm{~g} / \mathrm{mL}$, total acidity of $6.7 \mathrm{~g} / \mathrm{L}$ and a $\mathrm{pH}$ of 3.65) and in good sanitary conditions.

Grapes were destemmed and crushed and the must was distributed in stainless steel tanks of $220 \mathrm{~L}$. Wines were made under different maceration conditions by applying two proportion of chips ( 3 and $6 \mathrm{~g} / \mathrm{L}$ ) and two maceration times ( 5 and 10 days), compared with a traditional macerated red wine. American oak (Quercus alba) low-toasted chips of $1 \mathrm{~cm}^{2}$ average size (Tonelería Martín y Vázquez, Logroño, Spain) were used. All maceration treatments were made in triplicate as follows:

\subsubsection{Traditional maceration}

3 tanks were submitted to traditional grape maceration (without oak chips) for 5 maceration days (C5 wines); and 3 tanks for 10 maceration days ( $\mathrm{C} 10$ wines). Both $\mathrm{C} 5$ and $\mathrm{C} 10$ wines were considered as control (C) wines.

\subsubsection{Oak chips-grape maceration at $3 \mathrm{~g} / \mathrm{L}$ of oak chips}

3 tanks were submitted to the addition of $3 \mathrm{~g} / \mathrm{L}$ of oak chips to the fermentation mash for 5 maceration days (S5 wines); and 3 tanks were submitted to the addition of $3 \mathrm{~g} / \mathrm{L}$ of oak chips to the fermentation mash for 10 maceration days (S10 wines). Both S5 and S10 were considered as wines made with simple amount of oak chips $(\mathrm{S}, 3 \mathrm{~g} / \mathrm{L})$ into the fermentation mash.

\subsubsection{Oak chips-grape maceration at $6 \mathrm{~g} / \mathrm{L}$ of oak chips}

3 tanks were submitted to the addition of $6 \mathrm{~g} / \mathrm{L}$ of oak chips to the fermentation mash for 5 maceration days (D5 wines); and 3 tanks were submitted to the addition of $6 \mathrm{~g} / \mathrm{L}$ of oak chips to the fermentation mash for 10 maceration days (D10 wines). Both D5 and D10 were considered as wines made with double amount of oak chips (D, $6 \mathrm{~g} / \mathrm{L}$ ) into the fermentation mash.

An identical red winemaking procedure was used for all assays. Oenological treatments were adjusted at the same levels for all of the assays: $60 \mathrm{mg} / \mathrm{L}$ total sulphur dioxide and $7 \mathrm{~g} / \mathrm{L}$ of total titratable acidity by adding tartaric acid. For all wines, alcoholic fermentation was spontaneously developed. Fermentation caps were punched down once a day during the maceration period. After this, the mash was drawn off to remove the skins and other solid parts, and the free run musts were left to finish the fermentation under the same conditions. Subsequently, the malolactic fermentation was induced by inoculation of Oenococcus oeni lactic acid bacteria ( $>10^{10}$ CFU 0. oeni/mL, VINIFERM Oe 104 , Agrovin, Spain) at the rate of $14 \mathrm{~mL} / \mathrm{hL}$ at the end of alcoholic fermentation. When fermentative processes were finished, the wines were racked in $50 \mathrm{~L}$ stainless steel tanks and stored at $10-15^{\circ} \mathrm{C}$ for a stabilisation period of 6 months.

Must and wine samples $(100 \mathrm{~mL})$ were taken at the initial point or grape crushing (1 day), at the middle of the fermentative alcoholic maceration (3 days), just after the skin removal (5 and 10 days), and 3 and 6 months during stabilisation period. A total of 108 samples were analysed in triplicate.

\subsection{HPLC-DAD-ESI/MS analysis of phenolic compounds}

HPLC separation, identification and quantification of anthocyanin and flavonols was performed in an Agilent 1200 chromatographic system equipped with a quaternary pump, an UV-vis diode-array detector, an automatic injector, and ChemStation software (Palo Alto, CA, USA). Prior direct injection, the samples were filtered through a $0.45 \mathrm{~lm}$ Nylon filter (E0034, Análisis Vínicos, Spain). All analyses were performed in triplicate. The anthocyanin and flavonols identification was carried out following the method proposed by Gordillo, Cejudo-Bastante, Rodríguez-Pulido, Lourdes González-Miret, and Heredia (2013). Phenolic compounds were separated using a Zorbax C18 column $(250 \mu \mathrm{m} 4.6 \mathrm{~mm}, 5 \mu \mathrm{m}$ particle size) maintained at $38^{\circ} \mathrm{C}$. Acetonitrile-formic acid-water (3:10:87) as solvent $A$ and acetonitrile-formic acid-water (50:10:40) as solvent $B$ were used. The elution profile was as follows: $0-10 \mathrm{~min} 94 \% \mathrm{~A} ; 10-15 \mathrm{~min} 70 \% \mathrm{~A} ; 15-25 \mathrm{~min} 60 \% \mathrm{~A}$; $25-$ 35 min 55\%A; 35-40 min 50\%A; 40-42 min 40\%A; 42-43 min 94\% A. The flow rate was $0.8 \mathrm{~mL} / \mathrm{min}$ and the injection volume was $50 \mu \mathrm{L}$. UV-vis spectra were recorded from 200 to $800 \mathrm{~nm}$ with a bandwidth of $2.0 \mathrm{~nm}$. The quantification was made at 525 and $360 \mathrm{~nm}$ (anthocyanin and flavonols, respectively) using the calibration curves obtained in the same chromatographic conditions for malvidin 3-glucoside and quercetin standards. The concentration of phenolic compounds was expressed as $\mathrm{mg} / \mathrm{L}$.

For flavan-3-ol and phenolic acid analysis, samples were fractionated prior to chromatographic analysis previously described by González-Manzano, Santos-Buelga, Pérez-Alonso, RivasGonzalo, and Escribano-Bailón (2006). Briefly, Oasis ${ }^{\circledR}$ MCX (Waters Corporation Mildford, MA, USA) cartridges were used for the separation of flavan-3-ols and phenolic acids. $1 \mathrm{~mL}$ of each wine was diluted (1:1) with $0.1 \mathrm{M} \mathrm{HCl}$ and eluted through previously conditioned cartridges. Anthocyanins and flavonols were retained in the cartridges while flavan-3-ols and phenolic acids were eluted with $8 \mathrm{~mL}$ of methanol. A small volume of water was added to the eluate and concentrated under vacuum at lower than $30^{\circ} \mathrm{C}$ until complete elimination of methanol. The volume of the aqueous residue was adjusted to $0.5 \mathrm{~mL}$ with ultrapure water, filtered $(0.45 \mu \mathrm{m})$ and 
analysed by HPLC-DAD-MS as previously described. The abovementioned HPLC system was coupled to a hybrid triple quadrupole/linear ion trap (QqLIT) mass spectrometer API 3200 QTrap (Applied Biosystems, Foster City, CA, USA) equipped with a Turbo V ionisation source and controlled by Analyst software (version 1.5; Applied Biosystems) via the DAD cell outlet. Phenolic acids and flavan-3-ol chromatographic separation was performed on a reversed-phase column Spherisorb ODS-2 $(150 \times 4.6 \mathrm{~mm}$, $3 \mu \mathrm{m}$ ) from Waters (Milford, MA, USA) maintained at $25^{\circ} \mathrm{C}$. $0.25 \%$ acetic acid in water (A) and acetonitrile (B) were used as the mobile phases The following linear gradient was used to achieve the chromatographic separation: from $0 \%$ to $10 \%$ B in $5 \mathrm{~min}$, from $10 \%$ to $14.5 \% \mathrm{~B}$ in $35 \mathrm{~min}$, from $14.5 \%$ to $19 \% \mathrm{~B}$ in $5 \mathrm{~min}$, from $19 \%$ to $55 \%$ B in $5 \mathrm{~min}$, hold at $55 \%$ B for $5 \mathrm{~min}$, from $55 \%$ to $80 \%$ B in $5 \mathrm{~min}$, hold at $80 \%$ B for $3 \mathrm{~min}$, from $80 \%$ to $0 \%$ B in $2 \mathrm{~min}$ and hold at $0 \% \mathrm{~B}$ for $5 \mathrm{~min}$. The flow rate was set at $0.5 \mathrm{~mL} \mathrm{~min}^{-1}$ and the injection volume was $100 \mu \mathrm{L}$. UV-vis spectra were recorded from 200 to $600 \mathrm{~nm}$, while acquiring at the selected wavelengths of $280 \mathrm{~nm}$ for flavan-3-ols quantification and $330 \mathrm{~nm}$ for phenolic acids.

The mass spectrometer was operated in the negative electrospray ionisation (ESI) mode under the following specific conditions: IS: $-4500 \mathrm{~V}$; source temperature (TEM), $400{ }^{\circ} \mathrm{C}$; CUR: 20 psi; GS1: 40 psi; GS2: 30 psi; DP: $-40 \mathrm{~V}$; EP: $-7 \mathrm{~V}$; and CE: $-20 \mathrm{eV}$. Nitrogen (>99.98\%) was employed as curtain, ion source and collision gas. The detection was accomplished in the enhanced MS (EMS) full-scan mode, from $m / z 100$ to 1700 , and in the enhanced product ion (EPI) mode, to obtain the corresponding full-scan MS/MS spectra.

Phenolic compounds were identified by comparison of their retention time, UV-vis spectra and mass spectra features with data reported in the literature and the previously recorded in our laboratory. The phenolic acids quantification was made at $330 \mathrm{~nm}$ using external calibration curves of purchased standards, using gallic acid for gallic acid quantification and $p$-coumaric acid for the rest of identified phenolic acids. Flavan-3-ols were quantified using external calibration curves recorded at $280 \mathrm{~nm}$ of its corresponding purchased standard. Phenolic compounds concentration was expressed as $\mathrm{mg} / \mathrm{L}$.

\subsection{Colorimetric analysis}

The absorption spectra $(380-770 \mathrm{~nm})$ of wine samples were recorded at constant intervals $(\Delta \lambda=2 \mathrm{~nm})$ with a HewlettPackard UV-vis HP8453 spectrophotometer (Palo Alto, CA), using $2 \mathrm{~mm}$ path length glass cells and distiled water as a reference. The CIELAB parameters were calculated by Tristimulus Colorimetry from the absorption spectra by using the original software CromaLab@ (Heredia, Álvarez, González-Miret, \& Ramírez, 2004) and following the recommendations of the Commission International de L'Eclariage: the CIE $196410^{\circ}$ Standard Observer and the Standard Illuminant D65. CIELAB parameters were calculated: $\mathrm{L}^{*}$ (the correlate of lightness; ranging from 0, black, to 100, white), and two colour coordinates, $a^{*}$ (which takes positive values for reddish colours and negative values for greenish ones) and $\mathrm{b}^{*}$ (positive for yellowish colours and negative for the bluish ones). From these coordinates, other colour parameters are defined: the hue angle $\left(h_{a b}\right.$, the correlate of chromaticity or tone, and the chroma $\mathrm{C}_{\mathrm{ab}}^{*}$, the correlate of saturation or intensity of colour). $L^{*}, C_{a b}^{*}$ and $h_{a b}$ can be distinguished as quantitative or qualitative parameters as they indicate quantitative $\left(\mathrm{L}^{*}\right.$ and $\left.\mathrm{C}_{\mathrm{ab}}^{*}\right)$, or qualitative $\left(\mathrm{h}_{\mathrm{ab}}\right)$ attributes of colour.

The colour changes of wines during maceration and their colour stability over the storage period were evaluated by Differential Colorimetry according to the methodology described in Gordillo et al. (2015), which is based on the application of various different colour-difference formulas in the CIELAB space. The colour difference between pairs of samples were computed as the Euclidean distance between two points in the three-dimensional CIELAB space by means of the CIE76 colour difference formulae: $\Delta \mathrm{E}_{\mathrm{ab}}^{*}=$ $\left.\left[\left(\Delta \mathrm{L}^{*}\right)^{2}+\left(\Delta \mathrm{a}^{*}\right)^{2}+\left(\Delta \mathrm{b}^{*}\right)^{2}\right]^{1 / 2}\right)$. Moreover, the trend of the changes in each individual colour attribute between pairs of samples was evaluated by means of the absolute lightness, chroma, and hue differences $\left(\Delta \mathrm{L}^{*}, \mathrm{C}_{\mathrm{ab}}^{*}, \Delta \mathrm{h}_{\mathrm{ab}}\right)$. Specifically, $\Delta \mathrm{h}_{\mathrm{ab}}$ is the difference between two hues, in sexagesimal degrees.

\subsection{Copigmented and polymerised anthocyanin determination}

The contribution of copigmented anthocyanins to the total wine colour at pH 3.6 (\% Copigmentation) and the degree of anthocyanin polymerisation (\% Polymerisation) were determined following the method proposed by Boulton (1996). The $\mathrm{pH}$ values of the wine sample were previously adjusted to $\mathrm{pH} 3.6$ using $1 \mathrm{M} \mathrm{NaOH}$ or $\mathrm{HCl}$.

Total wine colour is assumed to be $A^{\text {acet }}$, the measure of absorbance at $520 \mathrm{~nm}$ after the elimination of $\mathrm{SO}_{2}$ effect by means of the addition of $20 \mu \mathrm{l}$ of $10 \%$ acetaldehyde to $2 \mathrm{ml}$ of wine sample, and kept for $45 \mathrm{~min}$. The colour due to polymeric pigments is $\mathrm{A}^{\mathrm{SO}^{2}}$, the absorbance measured at $520 \mathrm{~nm}$ after the addition of $160 \mu 15 \% \mathrm{SO}_{2}$ solution to $2 \mathrm{ml}$ of wine sample. The wine colour without the copigmented anthocyanins effect is $\mathrm{A}^{20}$, the absorbance measured at $520 \mathrm{~nm}$ of the wine sample diluted 1:20 with a buffer solution ( $24 \mathrm{ml}$ pure ethanol is added to $176 \mathrm{ml}$ distiled water, dissolve $0.5 \mathrm{~g}$ of potassium bitartrate into the solution. The solution $\mathrm{pH}$ is adjusted to 3.6 with $\mathrm{HCl}$ or $\mathrm{NaOH}$ as needed). The reading is corrected for the dilution by multiplying by 20 . That dilution leads to the dissociation of the copigment complex while the contributions of the free anthocyanins and the polymeric pigments remain. All absorbance readings are converted to $10 \mathrm{~mm}$ pathlength. The following data were calculated:

$$
\begin{aligned}
& \% \text { Copigmentation }=\left[\left(\mathrm{A}^{\text {acet }}-\mathrm{A}^{20}\right) / \mathrm{A}^{\text {acet }}\right] \times 100 \\
& \% \text { Polymerisation }=\left(\mathrm{A}^{\mathrm{SO}_{2}} / \mathrm{A}^{\text {acet }}\right) \times 100
\end{aligned}
$$

\subsection{Statistical analysis}

Statistical analysis was carried out by using Statistica version 8.0 software (Statistica, 2007). In order to study significant differences between the different types of wines in terms of phenolic composition and colour characteristics, a multifactorial analysis of variance was carried out using the general linear model procedure (GLM). Tukey test was used to evaluate the significance of the analysis.

\section{Results and discussion}

\subsection{Changes in phenolic composition}

The extraction of phenolic compounds under different conditions of maceration time ( 5 and 10 days) and chip dose (0, 3 and $6 \mathrm{~g} / \mathrm{L}$ ) was studied to establish which of these factors have a greater impact in the quality of Syrah wines during winemaking when an oak chips-grape mix maceration process is applied respect to traditional maceration. In the qualitative analysis of phenolic composition, 27 compounds belonging to diverse phenolic families were identified by HPLC-MS: 10 anthocyanins, 6 phenolic acids, 4 flavan-3-ols, and 6 flavonols. Table 1 shows the mean concentration $(\mathrm{mg} / \mathrm{L} \pm \mathrm{SD}, n=3)$ of compounds identified in the wine samples at the end of the fermentative maceration period (skin 
Table 1

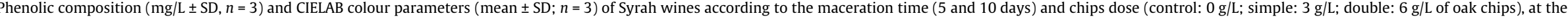
end of the maceration period (skin removal).

\begin{tabular}{|c|c|c|c|c|c|c|c|c|c|}
\hline & \multirow[b]{2}{*}{ C5 } & \multirow[b]{2}{*}{ S5 } & \multirow[b]{2}{*}{ D5 } & \multirow[b]{2}{*}{ C10 } & \multirow[b]{2}{*}{ S10 } & \multirow[b]{2}{*}{ D10 } & \multicolumn{3}{|l|}{ Effect } \\
\hline & & & & & & & Maceration time & Chips dose & Interaction \\
\hline \multicolumn{10}{|l|}{ Phenolic compounds } \\
\hline Sum of anthocyanins & $1429.5 \pm 3.6 \mathrm{a}$ & $1636.0 \pm 0.3 \mathrm{~b}$ & $1500.2 \pm 27.7 \mathrm{ab}$ & $1239.3 .5 \pm 42.6 c$ & $1170.9 \pm 37.4 \mathrm{~cd}$ & $1081.6 \pm 89.4 \mathrm{~d}$ & ${ }^{* * *}$ & * & $* *$ \\
\hline Sum of glucosides & $952.8 \pm 3.2 \mathrm{a}$ & $1094.3 \pm 0.9 \mathrm{~b}$ & $1013.2 \pm 13.7 \mathrm{ab}$ & $828.0 \pm 28.8 c$ & $775.6 \pm 19.9 \mathrm{~cd}$ & $710.0 \pm 54.8 \mathrm{~d}$ & ${ }^{* * *}$ & ** & *** \\
\hline Sum of acetates & $325.5 \pm 4.2 \mathrm{a}$ & $365.4 \pm 0.3 \mathrm{~b}$ & $331.2 \pm 5.9 \mathrm{a}$ & $279.1 \pm 6.8 \mathrm{c}$ & $270.5 \pm 8.8 \mathrm{c}$ & $254.2 \pm 17.8 \mathrm{c}$ & $* * *$ & $* *$ & ** \\
\hline Sum of coumaroylated & $151.2 \pm 0.2 \mathrm{ab}$ & $176.3 \pm 0.6 a$ & $155.7 \pm 7.7 \mathrm{ab}$ & $132.2 \pm 7.2 \mathrm{bc}$ & $124.8 \pm 9.1 c$ & $117.4 \pm 17.6 c$ & $* * *$ & ns & * \\
\hline Sum of phenolic acids & $181.1 \pm 2.0 \mathrm{a}$ & $181.2 \pm 3.8 \mathrm{a}$ & $184.8 \pm 5.2 \mathrm{a}$ & $107.3 \pm 9.2 \mathrm{~b}$ & $123.2 \pm 0.3 \mathrm{~b}$ & $112.7 \pm 0.8 \mathrm{~b}$ & $* * *$ & ns & ns \\
\hline Sum of flavan-3-ols & $127.7 \pm 2.3 \mathrm{a}$ & $148.7 \pm 1.4 \mathrm{~b}$ & $135.3 \pm 5.3 \mathrm{ab}$ & $148.8 \pm 0.5 \mathrm{ab}$ & $184.9 \pm 4.8 c$ & $169.9 \pm 0.1 c$ & ${ }^{* * *}$ & *** & * \\
\hline Sum of benzoic acids & $73.2 \pm 0.2 \mathrm{a}$ & $73.4 \pm 0.5 a$ & $78.2 \pm 0.1 \mathrm{~b}$ & $33.0 \pm 0.5 c$ & $48.1 \pm 0.3 \mathrm{~d}$ & $44.1 \pm 0.1 \mathrm{e}$ & ${ }^{* * *}$ & $* * *$ & *** \\
\hline Sum of hydroxycinnamic acids & $107.9 \pm 2.1 \mathrm{a}$ & $107.8 \pm 4.3 \mathrm{a}$ & $106.6 \pm 5.1 \mathrm{a}$ & $74.3 \pm 9.2 \mathrm{~b}$ & $75.2 \pm 0.8 \mathrm{~b}$ & $68.1 \pm 0.9 \mathrm{~b}$ & ${ }^{* * *}$ & ns & ns \\
\hline Sum of flavonols & $34.5 \pm 2.1 \mathrm{a}$ & $34.8 \pm 3.6 \mathrm{a}$ & $33.3 \pm 1.4 \mathrm{a}$ & $36.1 \pm 7.8 \mathrm{a}$ & $30.3 \pm 2.2 \mathrm{a}$ & $29.1 \pm 5.9 \mathrm{a}$ & ns & ns & ns \\
\hline \multicolumn{10}{|l|}{ Anthocyanins } \\
\hline Delphinidin 3-glucoside & $55.9 \pm 1.8 \mathrm{a}$ & $70.4 \pm 0.1 \mathrm{~b}$ & $63.8 \pm 1.6 \mathrm{~b}$ & $46.6 \pm 1.8 \mathrm{c}$ & $40.9 \pm 1.5 \mathrm{c}$ & $34.1 \pm 4.6 \mathrm{~d}$ & ${ }^{* * *}$ & ** & $* * *$ \\
\hline Petunidin 3-glucoside & $99.9 \pm 1.9 \mathrm{a}$ & $123.2 \pm 1.2 \mathrm{~b}$ & $110.5 \pm 1.1 \mathrm{a}$ & $83.5 \pm 3.9 \mathrm{c}$ & $78.5 \pm 2.1 \mathrm{c}$ & $66.7 \pm 7.6 \mathrm{~d}$ & $* * *$ & ** & *** \\
\hline Peonidin 3-glucoside & $78.6 \pm 1.9 \mathrm{a}$ & $98.7 \pm 0.4 \mathrm{~b}$ & $96.5 \pm 6.5 \mathrm{~b}$ & $76.7 \pm 2.6 \mathrm{ac}$ & $72.3 \pm 2.3 \mathrm{ac}$ & $64.9 \pm 8.5 c$ & ${ }^{* * *}$ & * & *** \\
\hline Malvidin 3-glucoside & $718.4 \pm 11.4 \mathrm{a}$ & $802.1 \pm 6.1 \mathrm{~b}$ & $724.4 \pm 17.4 \mathrm{ab}$ & $621.3 \pm 20.9 c$ & $583.8 \pm 15.3 \mathrm{~cd}$ & $544.3 \pm 34.8 \mathrm{~d}$ & ${ }^{* * *}$ & $* *$ & $* * *$ \\
\hline Petunidin 3-acetyl-glucoside & $24.9 \pm 1.1 \mathrm{a}$ & $29.2 \pm 0.4 \mathrm{~b}$ & $25.4 \pm 0.7 \mathrm{a}$ & $21.5 \pm 3.7 \mathrm{c}$ & $20.4 \pm 0.6 c$ & $17.5 \pm 1.4 \mathrm{~d}$ & ${ }^{* * *}$ & $* * *$ & ** \\
\hline Peonidin 3-acetyl-glucoside & $41.1 \pm 1.1 \mathrm{a}$ & $48.7 \pm 0.6 b$ & $45.0 \pm 0.1 \mathrm{ab}$ & $36.4 \pm 0.7 \mathrm{c}$ & $35.9 \pm 0.9 \mathrm{c}$ & $33.5 \pm 2.8 \mathrm{c}$ & $* * *$ & $* *$ & ** \\
\hline Malvidin 3-acetyl-glucoside & $259.6 \pm 2.1 \mathrm{a}$ & $287.4 \pm 0.1 \mathrm{~b}$ & $261.0 \pm 6.7 \mathrm{a}$ & $221.3 \pm 5.5 c$ & $214.2 \pm 7.5 c$ & $203.2 \pm 13.8 \mathrm{c}$ & ${ }^{* * *}$ & ** & ** \\
\hline Petunidin 3-p-coumaroil-glucoside & $16.7 \pm 0.3 a$ & $18.3 \pm 0.6 a$ & $16.8 \pm 1.4 \mathrm{a}$ & $13.9 \pm 0.6 b$ & $12.7 \pm 0.6 \mathrm{~b}$ & $11.3 \pm 1.7 \mathrm{~b}$ & $* * *$ & ns & ns \\
\hline Peonidin 3-p-coumaroil-glucoside & $41.1 \pm 0.8 \mathrm{ab}$ & $47.9 \pm 0.7 \mathrm{a}$ & $40.8 \pm 2.9 \mathrm{ab}$ & $34.5 \pm 2.5 b c$ & $32.8 \pm 2.9 \mathrm{bc}$ & $31.3 \pm 4.8 \mathrm{c}$ & $* * *$ & ns & ns \\
\hline Malvidin 3-p-coumaroil-glucoside & $93.3 \pm 0.3 a$ & $110.3 \pm 0.6 b$ & $98.2 \pm 3.4 \mathrm{ab}$ & $83.8 \pm 4.2 \mathrm{ac}$ & $79.3 \pm 5.8 \mathrm{ac}$ & $74.8 \pm 11.1 \mathrm{c}$ & $* * *$ & ns & * \\
\hline \multicolumn{10}{|l|}{ Benzoic acids } \\
\hline Gallic acid & $73.2 \pm 0.1 \mathrm{a}$ & $72.7 \pm 0.4 \mathrm{a}$ & $77.2 \pm 0.1 \mathrm{~b}$ & $33.0 \pm 0.1 \mathrm{c}$ & $46.8 \pm 0.4 \mathrm{~d}$ & $42.5 \pm 0.2 \mathrm{e}$ & ${ }^{* * *}$ & $* * *$ & $* * *$ \\
\hline Ellagic acid & $\operatorname{tr}$ & $0.7 \pm 0.2 \mathrm{a}$ & $1.03 \pm 0.1 b$ & $\operatorname{tr}$ & $1.3 \pm 0.2 \mathrm{~b}$ & $1.6 \pm 0.1 c$ & *** & ${ }^{* * *}$ & $* *$ \\
\hline \multicolumn{10}{|l|}{ Hydroxycinn. acids } \\
\hline$t$-Caftaric-protocatechuic acid & $54.7 \pm 0.1 \mathrm{a}$ & $51.2 \pm 0.6 \mathrm{a}$ & $49.7 \pm 0.7 \mathrm{a}$ & $37.6 \pm 4.5 \mathrm{~b}$ & $37.3 \pm 0.7 \mathrm{~b}$ & $33.1 \pm 1.1 \mathrm{~b}$ & ${ }^{* * *}$ & * & ns \\
\hline$c$-Coutaric acid & $3.5 \pm 2.1 \mathrm{a}$ & $3.2 \pm 1.7 \mathrm{a}$ & $2.2 \pm 0.1 \mathrm{a}$ & $2.9 \pm 0.9 \mathrm{a}$ & $3.6 \pm 0.3 a$ & $3.4 \pm 0.1 \mathrm{a}$ & ns & ns & ns \\
\hline$t$-Coutaric acid & $32.3 \pm 0.1 \mathrm{a}$ & $30.4 \pm 0.2 \mathrm{ab}$ & $34.7 \pm 1.0 \mathrm{a}$ & $20.6 \pm 2.8 \mathrm{bc}$ & $20.9 \pm 0.3 b c$ & $17.7 \pm 0.3 c$ & $* * *$ & ns & ns \\
\hline Fertaric acid & $8.2 \pm 0.3 \mathrm{a}$ & $7.7 \pm 0.7 \mathrm{a}$ & $7.1 \pm 0.1 \mathrm{a}$ & $6.2 \pm 1.2 \mathrm{a}$ & $6.5 \pm 0.3 a$ & $6.3 \pm 0.1 \mathrm{a}$ & ${ }^{* *}$ & ns & ns \\
\hline Coumaric hexose acid & $4.7 \pm 5.5 \mathrm{a}$ & $10.3 \pm 1.7 \mathrm{~b}$ & $9.1 \pm 2.2 \mathrm{~b}$ & $3.8 \pm 0.1 \mathrm{a}$ & $3.5 \pm 0.2 \mathrm{a}$ & $4.3 \pm 0.4 a$ & ${ }^{* * *}$ & $* *$ & $* *$ \\
\hline Caffeic acid & $4.4 \pm 2.1 \mathrm{a}$ & $5.0 \pm 0.1 \mathrm{a}$ & $3.8 \pm 0.1 \mathrm{ab}$ & $3.1 \pm 0.3 b$ & $3.2 \pm 0.1 b$ & $3.3 \pm 0.1 b$ & ${ }^{* *}$ & ns & ns \\
\hline \multicolumn{10}{|l|}{ Flavan-3-ols } \\
\hline Galocatechin(GC) & $101.5 \pm 0.7 a$ & $122.7 \pm 0.9 \mathrm{ac}$ & $109.4 \pm 4.2 \mathrm{ac}$ & $101.3 \pm 6.5 \mathrm{a}$ & $125.8 \pm 1.5 \mathrm{~b}$ & $118.1 \pm 0.7 \mathrm{bc}$ & ** & $* *$ & ns \\
\hline Procyanindin B3 & $11.1 \pm 0.3 \mathrm{a}$ & $18.7 \pm 0.1 \mathrm{~b}$ & $11.1 \pm 0.1 \mathrm{a}$ & $10.6 \pm 0.2 \mathrm{a}$ & $13.4 \pm 0.2 \mathrm{c}$ & $18.5 \pm 0.6 \mathrm{~b}$ & ns & *** & *** \\
\hline$(+)$-Catechin & $9.8 \pm 0.6 \mathrm{ab}$ & $11.7 \pm 0.4 \mathrm{~b}$ & $9.2 \pm 0.2 \mathrm{a}$ & $17.8 \pm 0.2 \mathrm{c}$ & $19.7 \pm 0.9 c$ & $14.9 \pm 0.4 \mathrm{~d}$ & ${ }^{* * *}$ & *** & * \\
\hline (-)-Epicatechin & $5.2 \pm 0.4 a$ & $5.4 \pm 0.9 a$ & $5.6 \pm 0.7 a$ & $15.0 \pm 1.2 b$ & $25.8 \pm 2.2 c$ & $15.5 \pm 2.9 b$ & *** & $* *$ & ** \\
\hline \multicolumn{10}{|l|}{ Flavonols } \\
\hline Myricetin 3-glucuronide & $8.9 \pm 0.6 a$ & $8.8 \pm 0.8 a$ & $8.5 \pm 0.4 a$ & $8.9 \pm 0.2 \mathrm{a}$ & $7.8 \pm 0.5 \mathrm{a}$ & $7.6 \pm 0.8 \mathrm{a}$ & ${ }^{* *}$ & * & ns \\
\hline Quercetin 3-glucuronide & $6.7 \pm 0.6 \mathrm{a}$ & $6.7 \pm 0.7 \mathrm{a}$ & $6.4 \pm 0.1 \mathrm{a}$ & $8.2 \pm 0.3 a$ & $7.2 \pm 0.7 \mathrm{a}$ & $7.1 \pm 1.3 \mathrm{a}$ & ns & ns & ns \\
\hline Quercetin 3-glucoside & $12.1 \pm 0.4 \mathrm{a}$ & $12.0 \pm 1.1 \mathrm{a}$ & $11.5 \pm 0.5 \mathrm{a}$ & $10.5 \pm 0.3 \mathrm{a}$ & $9.6 \pm 0.6 a$ & $10.8 \pm 1.3 \mathrm{a}$ & ** & ns & ns \\
\hline Kaempferol 3-glucoside & $0.5 \pm 0.1 \mathrm{a}$ & $0.6 \pm 0.2 \mathrm{a}$ & $0.5 \pm 0.2 \mathrm{a}$ & $0.3 \pm 0.1 \mathrm{a}$ & $0.3 \pm 0.1 \mathrm{a}$ & $0.2 \pm 0.1 \mathrm{a}$ & ${ }^{* * *}$ & ns & ns \\
\hline Isorhamnetin 3-glucoside & $3.9 \pm 0.4 a$ & $3.4 \pm 0.1 \mathrm{a}$ & $3.8 \pm 0.5 a$ & $4.5 \pm 0.1 \mathrm{a}$ & $3.9 \pm 0.2 \mathrm{a}$ & $4.0 \pm 0.4 a$ & ns & ns & ns \\
\hline Syringetin 3-glucoside & $2.3 \pm 0.2 \mathrm{a}$ & $2.6 \pm 0.3 a$ & $2.5 \pm 0.1 \mathrm{a}$ & $3.3 \pm 0.1 \mathrm{a}$ & $2.8 \pm 0.1 \mathrm{a}$ & $2.7 \pm 0.3 a$ & ${ }^{* *}$ & * & ** \\
\hline \multicolumn{10}{|l|}{ Colour data } \\
\hline $\mathrm{L}^{*}$ & $58.9 \pm 0.3 a$ & $58.8 \pm 0.9 a$ & $59.3 \pm 0.3 a$ & $60.7 .5 \pm 0.3 \mathrm{ab}$ & $61.5 \pm 0.2 \mathrm{ab}$ & $64.5 \pm 2.9 \mathrm{~b}$ & ** & ns & ns \\
\hline$a^{*}$ & $50.1 \pm 0.2 \mathrm{a}$ & $53.5 \pm 1.1 \mathrm{~b}$ & $50.9 \pm 1.3 \mathrm{a}$ & $44.4 \pm 0.2 c$ & $43.3 \pm 0.3 c$ & $39.6 \pm 2.8 \mathrm{~d}$ & $* * *$ & $* * *$ & * \\
\hline $\mathrm{b}^{*}$ & $-5.3 \pm 0.1 \mathrm{a}$ & $-5.7 \pm 0.1 \mathrm{a}$ & $-5.3 \pm 0.5 a$ & $-3.7 \pm 0.1 \mathrm{~b}$ & $-3.3 \pm 0.1 b c$ & $-4.3 \pm 0.4 \mathrm{c}$ & ${ }^{* * *}$ & ns & $* *$ \\
\hline $\mathrm{C}_{\mathrm{ab}}^{*}$ & $50.2 \pm 0.3 a$ & $53.8 \pm 1.1 \mathrm{~b}$ & $51.1 \pm 1.3 \mathrm{a}$ & $44.6 \pm 0.3 \mathrm{c}$ & $43.4 \pm 0.3 c$ & $39.8 \pm 2.7 \mathrm{~d}$ & ${ }^{* * *}$ & $* * *$ & *** \\
\hline$h_{a b}$ & $-6.0 \pm 0.1 \mathrm{a}$ & $-6.3 \pm 0.4 a$ & $-5.9 \pm 0.4 a$ & $-4.7 \pm 0.2 \mathrm{~b}$ & $-4.4 \pm 0.1 \mathrm{~b}$ & $-6.1 \pm 1.1 \mathrm{~b}$ & ${ }^{* *}$ & ns & ** \\
\hline
\end{tabular}

tr: traces; different letters in the same row mean significant differences (ns: no significant; ${ }^{*} p<0.05 ; "{ }^{* \prime} p<0.01 ; "{ }^{* * *} p<0.001$ ). 
removal), grouped according to their maceration time and chip dose applied.

The data were subjected to a multifactor analysis of variance by using the general linear model procedure (GLM, Tukey Test) for testing the significance of the effects of the factors on the phenolic composition. In addition, new dependent variables were calculated as the sum of individual phenolic compounds identified for each phenolic family (anthocyanins and their derivatives; phenolic, benzoic and hydroxycinnamic acids; flavan-3-ols and flavonols). They were included in the multifactorial analysis to know whether a combination of phenolics grouped into phenolic families varies as a function of the assayed factors.

The results indicated that the maceration time and the proportion of chips applied during the alcoholic fermentative maceration had a significant influence ( $p$-values of 0.018 and 0.02 , respectively) on the extraction of some phenolic families. The interaction effects between the factors were significant for the sum of anthocyanins and flavan-3-ols content, which are abundant phenolic compounds in red grapes and oak chips, respectively (Waterhouse, 2002). Although there was no interaction effect on the total content of phenolic acids, it was significant for the sum of benzoic acids, which are also grape/oak chips-related phenolic compounds (Cabrita, Barrocas Dias, \& Costa Freitas, 2011; Waterhouse, 2002). These significant interactions indicate possible synergistic or antagonistic effects of the studied factors both in pigments and copigments of wines.

In particular, the interaction effects showed the stronger influence (higher level of significance, $p<0.001$ ) of the maceration time on most of the individual anthocyanins and phenolic acids at skin removal, while the chip dose stronger influenced the benzoic acids and flavan-3-ol extraction.

It can be observed that shorter maceration times led to wines ( $C 5$, S5, and D5) with higher contents of anthocyanins (mainly glucosides and acetates; $p<0.001$ ) and phenolic acids (mainly gallic, $t$-caftaric-protocatechuic, and $t$-coutaric acids) than longer maceration time (C10, S10, and D10), which were in contrast richer in flava-3-ols (mainly (+)-catechin and epicatechin). The decrease of the anthocyanin content in extended macerations is in agreement with the results reported by other authors (Cheynier et al., 2006; González-Neves et al., 2010; González-Sáiz et al., 2014; Ivanova et al., 2011; Sacchi et al., 2005). This effect could be explained by the different reactions involving anthocyanins and other phenolic compounds easily diffused from the skin and pulp into the must in the first days of maceration. These competing processes such as oxidation, hydrolysis, condensation or polymerisation make them to be degraded or transformed progressively into new polymeric compounds (González-Neves et al., 2010). At the same time, oak chips fragments and solid parts of grapes might adsorb these compounds provoking a slowly decrease in their concentration from the earlier stages of vinification, especially when maceration is extended over time (Del Barrio-Galán et al., 2015; Gordillo et al., 2014). On contrast, longer maceration time (10 days) positively affected the extraction of some flavan-3-ols whose diffusion from skins and seeds into the must is favoured with higher alcohol content, sulphur dioxide, temperature, and contact time (Canals et al., 2008; Jensen, Blachez, Egebo, \& Meyer, 2007; Quijada-Morín, Hernández-Hierro, Rivas-Gonzalo, \& Escribano-Bailón, 2015).

Regarding the chips treatment, it seemed that the effect on the extraction of phenolic compounds varied according to the maceration time applied. In shorter maceration times (5 days), wines made in contact with oak chips (S5 and D5) had higher total contents of anthocyanins, benzoic acids and flavan-3-ols than traditional macerated wines (C5). However, the proportion of chips differently affected the content of each phenolic family. When the chip dose was increased, the total levels of anthocyanins and flavan-3-ols were slightly decreased while the levels of benzoic acids increased. Thus, S5 wines stated for their significant highest content in pigments, GC, procyanidin B3 and (+)-catechin; and D5 wines for being the richest in gallic and ellagic acids.

In the case of longer maceration times, wines made in contact with oak chips (S10 and D10) had significant higher content on the sum of flavan-3-ols and benzoic acids than traditional macerated wines (C10), but lower total anthocyanin content. However, the difference for the anthocyanin content was not significant between control and S10 wines. Other authors have also observed similar results in wines from different varieties macerated with oak chips during fermentation (Gordillo et al., 2014; Zimman et al., 2002). Thus, lower chip doses combined with higher maceration times led to wines (S10) with similar pigment content that traditional macerated wines but significantly richer in some copigments such as GC, procyanidin B3, (-)-epicatechin, gallic and ellagic acids.

On contrast, the increase of chip dose in the fermentation mash at longer maceration time produced a slightly decrease in some individual phenolic compounds that negatively influenced the total content of the phenolic families in D10 respect to S10 wines.

Finally, the maceration time and the chip dose applied did not influence the extraction of the individual flavonol compounds and so their total content in wines.

Figs. 1 and 2 shows the evolution of the total anthocyanin content $(\mathrm{mg} / \mathrm{L} \pm \mathrm{SD}, n=3)$ in 5 and 10 days macerated wines (respectively), and the percentage of copigmentation and polymerisation, during 6 months of storage. After pressing, a marked decrease of anthocyanins was observed in all wines but the pigment stability was influenced by the interaction of the maceration time and chip dose. It can be observed that the lowest pigment loss corresponded to S5 wines (30\%), that is, when the lower maceration wine was combined with the lower chip dose (Fig. 1A). On the contrary, the highest decreases in total anthocyanins corresponded to T10 and D10 wines (45\% and 40\% of total pigment loss, respectively), that is, when the higher maceration time and chips dose was applied (Fig. 2A).

With regard to the contribution of different group of pigments to the total colour (copigmented and polymeric pigments), the effect varied with the maceration time. In shorter maceration time (5 days), wines made in contact with oak chips (S5 and D5) reached higher levels of percentage of copigmentation and polymerisation than traditional macerated wines (C5), which confirm the positive effect of an oak chips-grape mix maceration in the phenolic structure of wines (Fig. 1B and C). This fact is in accordance with the higher extraction of specific colourless oak chips-related compounds that can act as good copigments (Table 1), as previously reported by other authors with similar maceration time and chip dose applied (Gordillo et al., 2014; Zimman et al., 2002). In longer macerated time (10 days), wines made in contact with oak chips (S10 and D10) reached again higher degree of copigmentation than traditional macerated wines, C10 (Fig. 2B). However, during the stabilisation period (from skin removal to the end of the storage), wines made with higher doses of chips (D10) showed the significant $(p<0.05)$ lowest degree of polymerisation and therefore, the lower pigment stability (Fig. 2C). This finding could be related with the higher adsorption of pigment and copigments extracted during the maceration stage respect to $\mathrm{C} 10$ and S10 wines.

\subsection{Changes in wine colour}

The changes in the colour parameters $\left(\mathrm{L}^{*}, \mathrm{C}_{\mathrm{ab}}^{*}\right.$, and $\mathrm{h}_{\mathrm{ab}}$; mean \pm SD, $n=3$ ) during winemaking in 5 and 10 days macerated wines, grouped by the chip dose, are shown in Figs. 3 and 4, respectively; as well as in Table 1. As can be observed, wine colour and its stability were noticeably influenced by the maceration treatment used. 
(A)

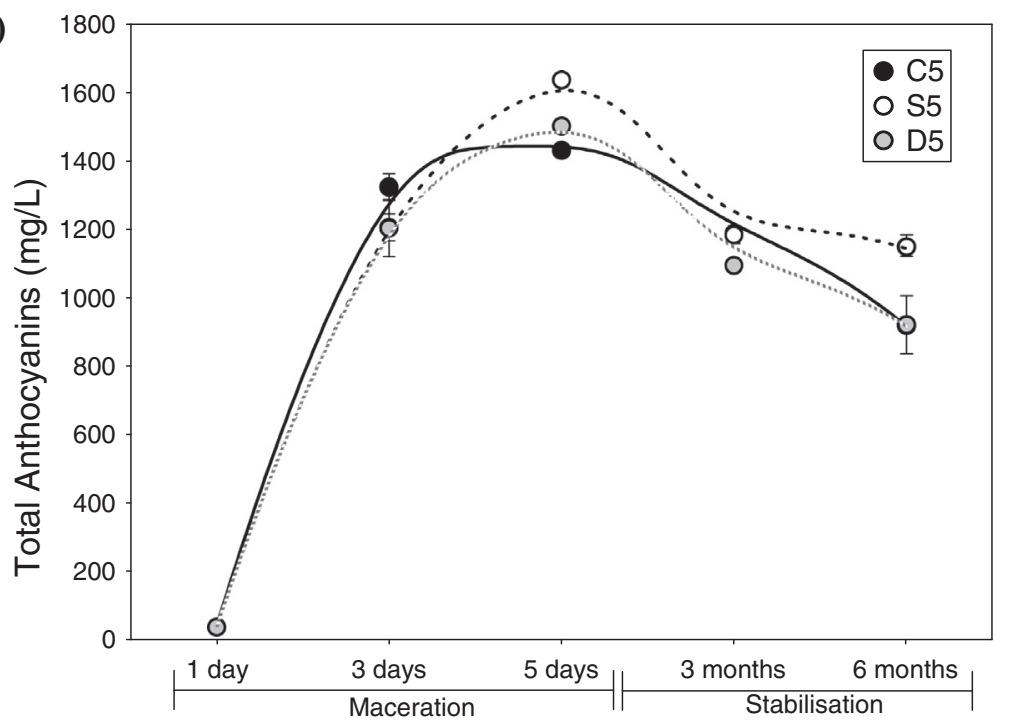

(B)

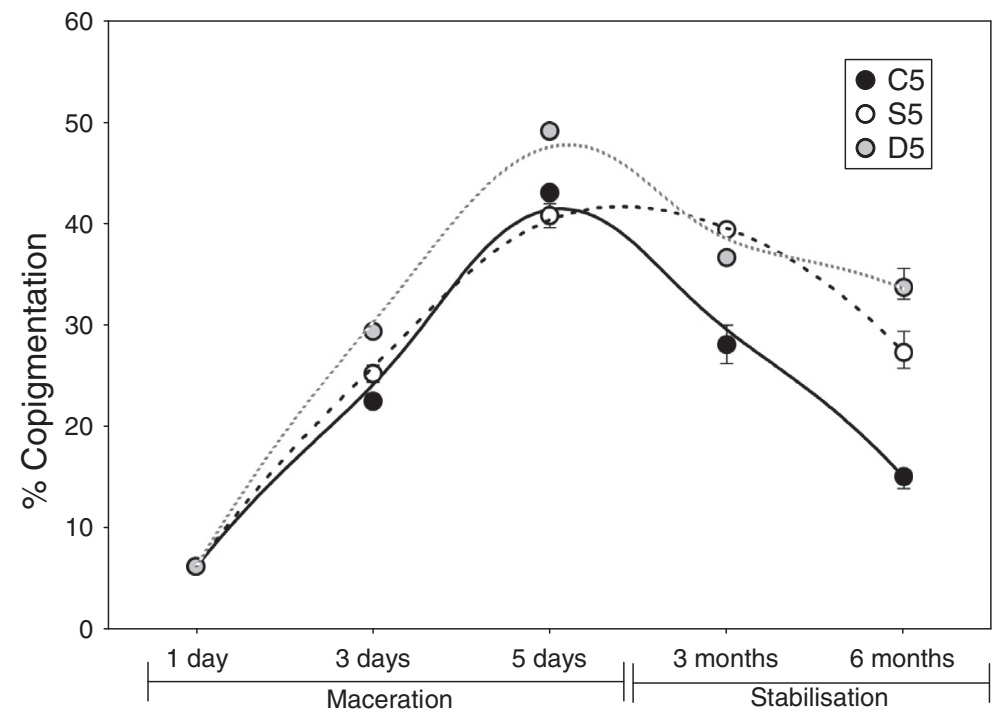

(C)

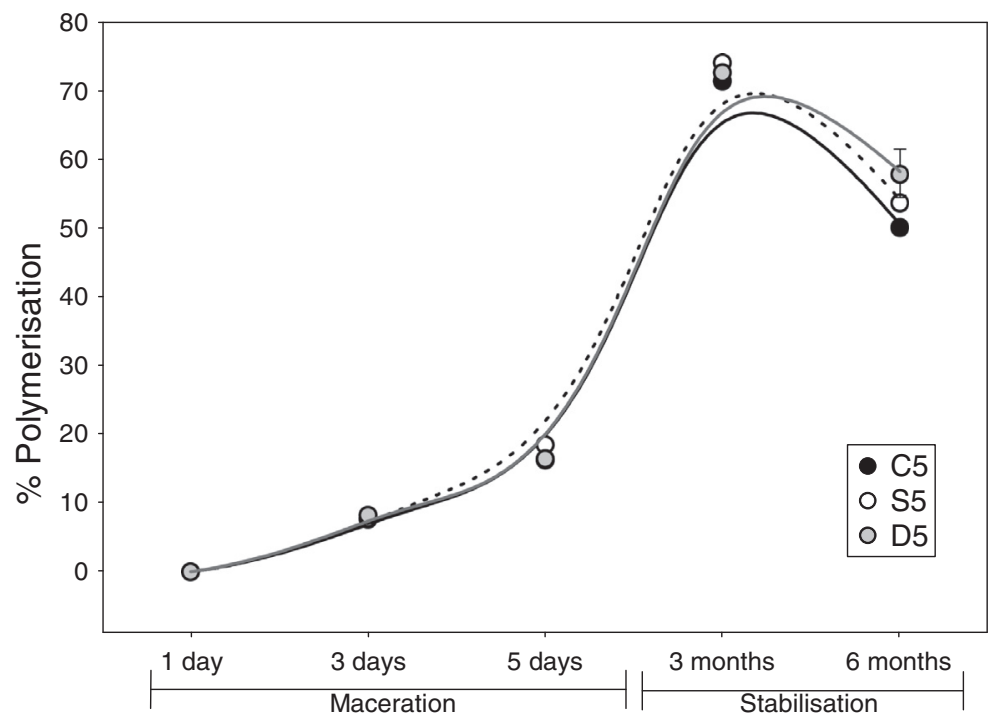

Fig. 1. Evolution of the (A) total anthocyanins, (B) percentage of copigmentation, and (C) percentage of polymerisation, in 5 days macerated wines during winemaking (C5: $0 \mathrm{~g} / \mathrm{L}, \mathrm{S5}: 3 \mathrm{~g} / \mathrm{L}, \mathrm{D} 5: 6 \mathrm{~g} / \mathrm{L}$ of oak chips). 

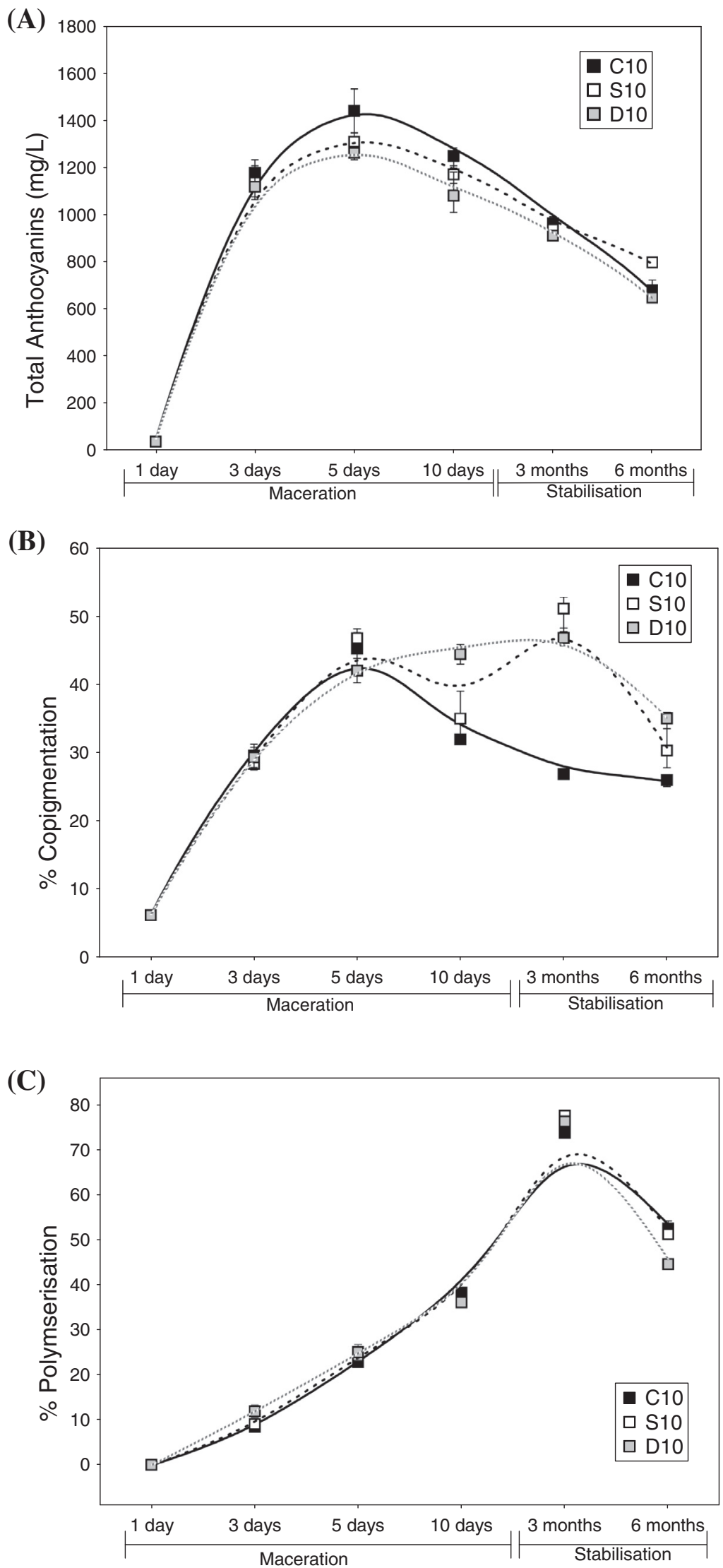

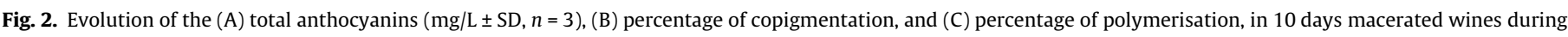
winemaking (C10: $0 \mathrm{~g} / \mathrm{L}, \mathrm{S} 10: 3 \mathrm{~g} / \mathrm{L}, \mathrm{D} 10: 6 \mathrm{~g} / \mathrm{L}$ of oak chips). 

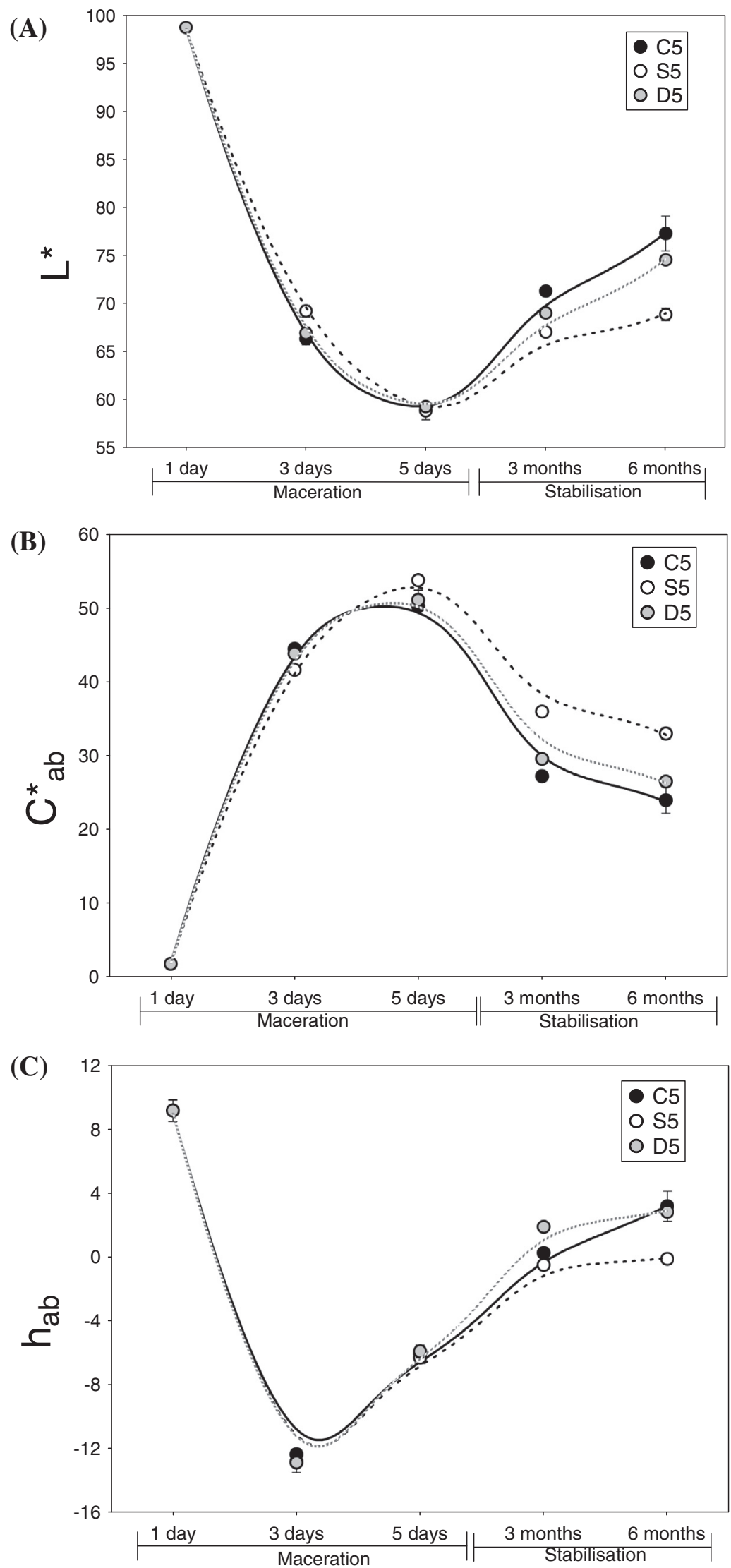

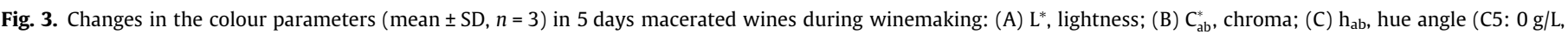
S5:3 g/L, D5: $6 \mathrm{~g} / \mathrm{L}$ of oak chips). 

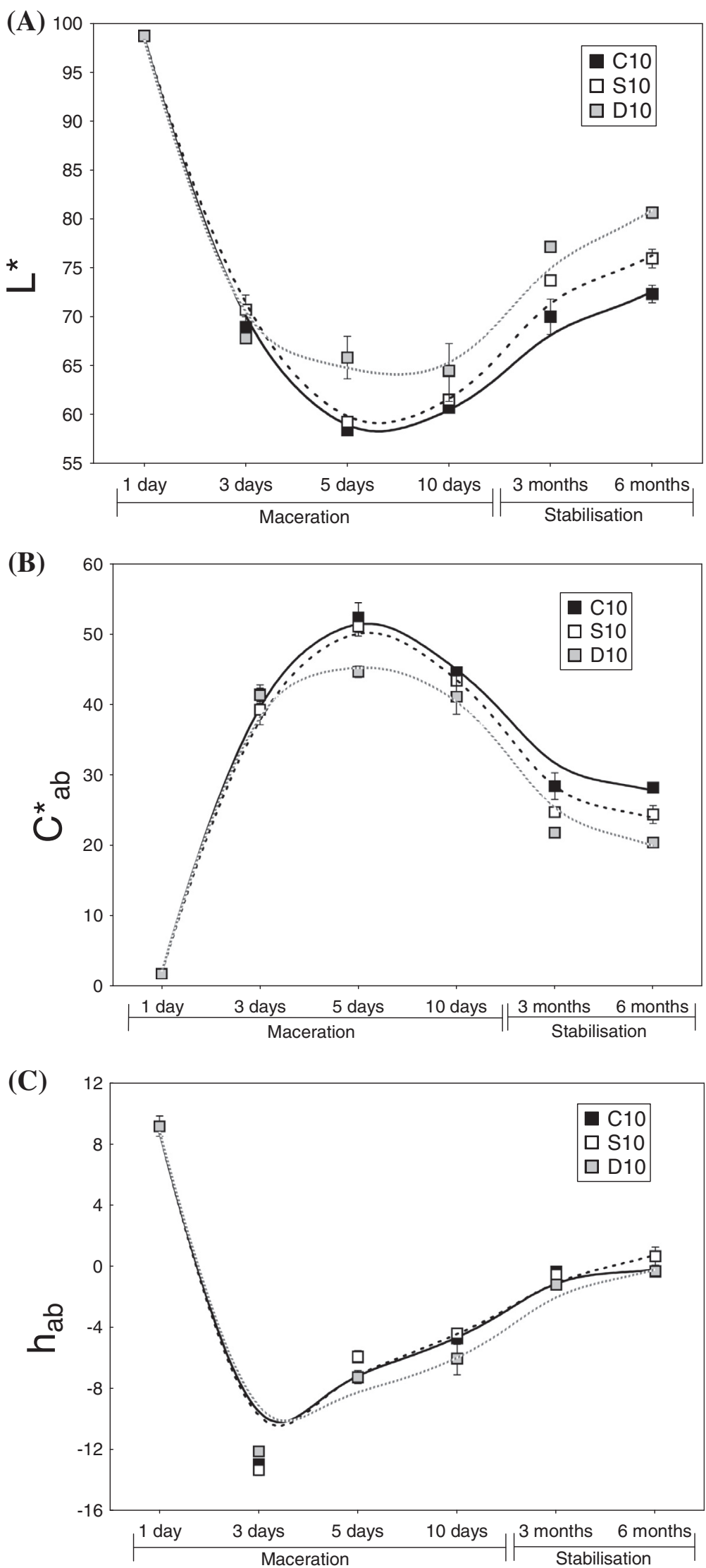

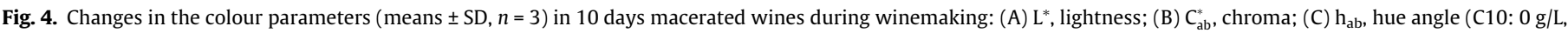
S10:3 g/L, D10: $6 \mathrm{~g} / \mathrm{L}$ of oak chips). 
Table 2

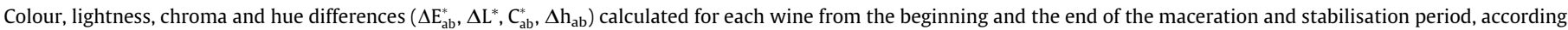
to the maceration time ( 5 and 10 days) and chips dose (Control: $0 \mathrm{~g} / \mathrm{L}$; Simple: $3 \mathrm{~g} / \mathrm{L}$; Double: $6 \mathrm{~g} / \mathrm{L}$ of oak chips).

\begin{tabular}{|c|c|c|c|c|c|c|c|c|c|c|}
\hline & & \multirow[b]{2}{*}{$\mathrm{C} 5$} & \multirow[b]{2}{*}{ S5 } & \multirow[b]{2}{*}{ D5 } & \multirow[b]{2}{*}{ C10 } & \multirow[b]{2}{*}{$\mathrm{S} 10$} & \multirow[b]{2}{*}{ D10 } & \multicolumn{3}{|l|}{ Effect } \\
\hline & & & & & & & & $\begin{array}{l}\text { Maceration } \\
\text { time }\end{array}$ & $\begin{array}{l}\text { Chips } \\
\text { dose }\end{array}$ & Interaction \\
\hline $\begin{array}{c}\text { Maceration } \\
\text { period }\end{array}$ & $\begin{array}{l}\Delta \mathrm{E}_{\mathrm{ab}}^{*} \\
\Delta \mathrm{L}^{*} \\
\mathrm{C}_{\mathrm{ab}}^{*} \\
\Delta \mathrm{h}_{\mathrm{ab}}\end{array}$ & $\begin{array}{l}62.7 \pm 0.1 \mathrm{a} \\
-39.7 \pm 0.3 \mathrm{a} \\
+48.4 \pm 0.3 \mathrm{a} \\
-15.2 \pm 0.7 \mathrm{ab}\end{array}$ & $\begin{array}{l}65.0 \pm 1.5 a \\
-38.9 \pm 1.8 a \\
+52.0 \pm 0.1 b \\
-15.4 \pm 0.3 a\end{array}$ & $\begin{array}{l}63.1 \pm 0.9 \mathrm{a} \\
-39.4 \pm 0.2 \mathrm{a} \\
+49.2 \pm 1.4 \mathrm{a} \\
-15.0 \pm 1.1 \mathrm{ab}\end{array}$ & $\begin{array}{l}57.3 \pm 0.4 b \\
-37.9 \pm 0.3 \mathrm{ab} \\
+42.7 \pm 0.3 \mathrm{c} \\
-13.8 \pm 0.7 \mathrm{ab}\end{array}$ & $\begin{array}{l}55.8 \pm 0.4 \mathrm{bc} \\
-37.2 \pm 0.2 \mathrm{ab} \\
+41.6 \pm 0.3 \mathrm{c} \\
-13.5 \pm 0.6 \mathrm{~b}\end{array}$ & $\begin{array}{l}52.1 \pm 4.0 \mathrm{c} \\
-34.2 \pm 3.0 \mathrm{~b} \\
+39.3 \pm 2.8 \mathrm{c} \\
-15.2 \pm 0.4 \mathrm{ab}\end{array}$ & $\begin{array}{l}* * * \\
* * \\
* * * \\
* *\end{array}$ & $\begin{array}{l}* \\
\text { ns } \\
* * \\
\text { ns }\end{array}$ & $\begin{array}{l}\text { ns } \\
\text { ns } \\
* * \\
\text { ns }\end{array}$ \\
\hline $\begin{array}{l}\text { Stabilisation } \\
\text { period }\end{array}$ & $\begin{array}{l}\Delta \mathrm{E}_{\mathrm{ab}}^{*} \\
\Delta \mathrm{L}^{*} \\
\mathrm{C}_{\mathrm{ab}}^{*} \\
\Delta \mathrm{h}_{\mathrm{ab}}\end{array}$ & $\begin{array}{l}33.8 \pm 1.2 \mathrm{a} \\
+19.2 \pm 0.8 \mathrm{ad} \\
-27.1 \pm 1.1 \mathrm{a} \\
+9.6 \pm 0.5 \mathrm{a}\end{array}$ & $\begin{array}{l}23.1 \pm 1.2 \mathrm{~b} \\
+9.1 \pm 2.2 \mathrm{~b} \\
-20.8 \pm 0.6 \mathrm{bd} \\
+6.2 \pm 0.3 \mathrm{~b}\end{array}$ & $\begin{array}{l}29.4 \pm 1.1 \mathrm{ad} \\
+15.2 \pm 0.3 \mathrm{ac} \\
-24.6 \pm 1.4 \mathrm{ab} \\
+8.7 \pm 0.4 \mathrm{a}\end{array}$ & $\begin{array}{l}20.2 \pm 1.2 b \\
+11.6 \pm 1.1 b c \\
-16.3 \pm 0.8 c \\
+4.3 \pm 0.2 c\end{array}$ & $\begin{array}{l}24.0 \pm 1.9 \mathrm{bc} \\
+14.4 \pm 1.2 \mathrm{~cd} \\
-19.0 \pm 1.5 \mathrm{~cd} \\
+5.0 \pm 0.5 \mathrm{bc}\end{array}$ & $\begin{array}{l}26.4 \pm 3.7 \mathrm{bcd} \\
+15.7 \pm 2.7 \mathrm{~d} \\
-20.7 \pm 2.6 \mathrm{bd} \\
+5.7 \pm 1.2 \mathrm{bc}\end{array}$ & $\begin{array}{l}* * * \\
\mathrm{~ns} \\
* * * \\
* * *\end{array}$ & $\begin{array}{l}* * * \\
* * \\
* * * \\
* *\end{array}$ & $\begin{array}{l}* * \\
* * * \\
* \\
* * *\end{array}$ \\
\hline
\end{tabular}

Different letters in the same row mean significant differences (ns: no significant; $p<0.05 ;{ }^{* *} p<0.01 ;{ }^{* * *} p<0.001$ )

At skin removal, the colour extraction was different for each maceration treatment but was coherent with the pigment extraction. As can be seen in Table 1, the interaction effects between the factors were significant for all the colorimetric parameters, except to the lightness $\left(\mathrm{L}^{*}\right)$. Results showed the stronger influence $(p<0.001)$ of the maceration time in both on quantitative $\left(\mathrm{L}^{*}, \mathrm{a}^{*}\right.$, $\mathrm{C}_{\mathrm{ab}}^{*}$ ) and qualitative $\left(\mathrm{b}^{*}, \mathrm{~h}_{\mathrm{ab}}\right.$ ) parameters, while the chip dose only influenced the quantitative ones $\left(\mathrm{a}^{*}, \mathrm{C}_{\mathrm{ab}}^{*}\right)$. As expected, the higher pigment extraction during fermentative maceration in shorter maceration wines, the significant higher values of chroma $\left(\mathrm{C}_{\mathrm{ab}}^{*}\right)$ and lower of hue $\left(h_{a b}\right)$ respect to longer maceration wines. Also, shorter macerated wines showed slightly lower values of lightness $\left(\mathrm{L}^{*}\right)$, but the differences were not significant for all wines. These results imply darker and more saturated bluish colour at skin removal respect to the extended maceration time (Ivanova et al., 2011).

On the other hand, the combination of increasing chip dose with shorter maceration time led to wines (S5 and D5) with higher values of $\mathrm{C}_{\mathrm{ab}}^{*}$ and lower of hue respect to traditional macerated wines (C5). However, these colorimetric differences were only significant for the quantitative colour attribute chroma $\left(\mathrm{C}_{\mathrm{ab}}^{*}\right)$ between C5 and S5 wines.

On contrast, the opposite effect was observed when longer maceration times were combined with chip dose, since lower values of chroma and higher of lightness were observed in S10 and D10 wines respect to traditional macerated wines (C10). These results were in accordance with the lower pigment extraction of wines macerated in contact with oak chips, especially those made with higher chip dose (D10).

The evolution of colour parameters over time was in agreement with the behaviour of the anthocyanin content of wines, as well as with the contribution of the different group of pigments to the total colour (copigmented and polymeric pigments). For shorter maceration times (5 days), S5 wines with significant higher anthocyanin content, proportion of copigments and copigmentation degree showed a more vivid bluish colour (higher chroma values and lower of hue) than traditional macerated wines or with $6 \mathrm{~g} / \mathrm{L}$ chips (Fig. 3B and C). At longer maceration time, wines summited to an oak chips-grape maceration process (S10 and D10 wines) showed lighter and less intense colour than traditional macerated wines, C10 (Fig. 4A and B). These differences were more marked when higher proportion of oak chips were applied (D10 wines). A similar behaviour was observed by Gordillo et al. (2014), when comparing the impact of adding white pomace to red grapes on the phenolic composition and colour stability of Syrah wines from a warm climate. In fact, higher pigment loss and lower degree of polymerisation (Fig. 2A and C) resulted in a net loss in colour in final wines.

Differential Tristimulus Colorimetry was applied to objectively asses the colour extraction and colour stability of each wine during vinification, and compare them according to the maceration time and the chip doses applied. For this purpose, colour, lightness, chroma and hue differences $\left(\Delta \mathrm{E}_{\mathrm{ab}}^{*}, \Delta \mathrm{L}^{*}, \mathrm{C}_{\mathrm{ab}}^{*}, \Delta \mathrm{h}_{\mathrm{ab}}\right.$, respectively) of wines were calculated during the extraction stage (from the grape crushing to the skin removal) and from the skin removal to the end of stabilisation period ( 6 months). Results obtained are shown in Table 2.

During the extraction period, wines submitted to shorter maceration times showed higher $\Delta \mathrm{E}_{\mathrm{ab}}^{*}$ values than longer macerated wines, indicating higher colour variation. The negative values obtained for $\Delta \mathrm{L}^{*}$ and $\Delta \mathrm{h}_{\mathrm{ab}}$ but positive for $\mathrm{C}_{\mathrm{ab}}^{*}$ are indicative of an increase of the quantity of colour of wines and to a displacement towards blue hue of wines, which is characteristic of the pigment extraction from grapes to wine. As observed, S5 wine presented the highest values of $\Delta \mathrm{E}_{\mathrm{ab}}^{*}(65.0)$ and $\mathrm{C}_{\mathrm{ab}}^{*}(+52$ CIELAB u.) but the lowest of $\Delta \mathrm{h}_{\mathrm{ab}}\left(-15.4^{\circ}\right)$. This observation means higher colour extraction, colour intensity and bluish tonality; which is in accordance with the colour parameters obtained at skin removal (Table 1), as well as the higher phenolic extraction (pigments and copigments) and degree of copigmentation in S5 wines.

During the stabilization period, according to the sign of $\Delta \mathrm{L}^{*}$, $\Delta \mathrm{C}_{\mathrm{ab}}^{*}$ and $\Delta \mathrm{h}_{\mathrm{ab}}$, higher $\Delta \mathrm{E}_{\mathrm{ab}}^{*}$ values are indicative of lower colour stability. In this sense, the combination of shorter maceration times with chip doses increased the colour stability of wines respect of those made with traditional grape maceration (lower $\Delta \mathrm{E}_{\mathrm{ab}}^{*}$ in S5 and D5 than C5 wines). This positive effect is supported by the higher degree of polymerisation reached at the end of the storage period in wines macerated with oak chips (\% Polymerisation $=54 \%$ and $57.8 \%$ in S5 and D5 versus $50 \%$ in C5 wines). However, the opposite effect was observed when longer maceration time was applied.

The combination of increasing chip dose in extended maceration time resulted in higher $\Delta \mathrm{E}_{\mathrm{ab}}^{*}$ values; and therefore, lower colour stability respect to traditional macerated wines. This behaviour was consistent with the lower degree of polymerisation in S10 and D10 wines at the end of the storage period (\% Polymerisation $=51 \%$ and $46 \%$ in S10 and D10 versus 53\% in C10 wines; Fig. 2C). These results are in agreement with those reported by Soto Vázquez et al. (2010) and González-Sáiz et al. (2014) for other varieties; which showed that the application of alternative maceration techniques do not always favour the reactions involved in anthocyanin stabilization in comparison to traditional winemaking due to the significant and complex interferences between process variables.

\section{Conclusions}

The application of an oak chips-grape mix maceration process during fermentation at the rates studied ( 3 and $6 \mathrm{~g} / \mathrm{L}$ ) increased the content of some colourless phenolics (flavanols and phenolic acids) that contribute to copigmentation reactions respect to the 
traditional grape maceration. Nevertheless, the effect on the pigment extraction depended on the maceration time used, which has remarkably consequences on the quality and stability of the wine colour. The application of oak chips at shorter maceration time ( 5 days) improved the anthocyanin extraction in young wines and their colour characteristics during stabilisation than traditional macerated wines, especially at lower chips proportion $(3 \mathrm{~g} /$ L). At longer maceration time (10 days), the addition of chips did not improved the extraction of pigments and colour probably due to a higher adsorption of compounds by the fermentation mash, resulting in lower colour stability. Therefore, the present study could be of great interest for the wine industry since results demonstrated in a comprehensive manner the advantages or disadvantages of applying a oak chips-grape mix maceration to modulate the phenolic composition and colour characteristics of red wines, especially in warm climate regions. It is also important to remark that the evaluation of oak-related compounds as ellagittanins should be considered in further work since might be a factor to better understand the relationship between colour and composition, in wines macerated in contact with oak chips.

\section{Acknowledgments}

We thank Ministerio de Economía y Competitividad (Project AGL2014-58486-C2) for financial support and the staff of Biology Service (SGI, Universidad de Sevilla) for the technical assistance. Berta Baca-Bocanegra holds a predoctoral research grant from the Universidad de Sevilla (V Plan Propio).

\section{References}

Alañón, M. E., Schumacher, R., Castro-Vázquez, L., Díaz-Maroto, M. C., HermosínGutiérrez, I. \& Pérez-Coello, M. S. (2013). Enological potential of chestnut wood for aging Tempranillo wines. Part II: Phenolic compounds and chromatic characteristics. Food Research International, 51(2), 536-543.

Añón, A., López, J. F., Hernando, D., Orriols, I., Revilla, E., \& Losada, M. (2014). Effect of five enological practices and of the general phenolic composition on fermentation-related aroma compounds in Mencia young red wines. Food Chemistry, 148, 268-275.

Boulton, R. B (1996). A method for the assessment of copigmentation in red wines. In In 47th annual meeting of the American society for enology and viticulture. Reno, NV.

Boulton, R. (2001). The copigmentation of anthocyanins and its role in the color of red wine: A critical review. American Journal of Enology and Viticulture, 52(2), 67-87.

Busse-Valverde, N., Gómez-Plaza, E., López-Roca, J. M., Gil-Muñoz, R., \& BautistaOrtín, A. B. (2011). The extraction of anthocyanins and proanthocyanidins from grapes to wine during fermentative maceration is affected by the enological technique. Journal of Agricultural and Food Chemistry, 59(10), 5450-5455.

Cabrita, M. J., Barrocas Dias, C., \& Costa Freitas, A. (2011). Phenolic acids, phenolic aldehydes and furanic derivatives in oak chips: American vs. French oaks. South African Journal of Enology and Viticulture, 32(2), 204-210.

Canals, R., Llaudy, M. C., Canals, J. M., \& Zamora, F. (2008). Influence of the elimination and addition of seeds on the colour, phenolic composition and astringency of red wine. European Food Research and Technology, 226(5), 1183-1190.

Cheynier, V., Dueñas-Paton, M. Salas, E, Maury, C, Souquet, J. M. Sarni-Manchado, P., \& Fulcrand, H. (2006). Structure and properties of wine pigments and tannins. American Journal of Enology and Viticulture, 57(3), 298-305.

CIE (2004). Technical report colorimetry.Vienna, Austria: Commission Internationale de l'Eclairage Central Bureau.

Darias-Martín, J., Carrillo, M., Díaz, E., \& Boulton, R. B. (2001). Enhancement of red wine colour by pre-fermentation addition of copigments. Food Chemistry, 73(2), 217-220.

Del Barrio-Galán, R., Medel-Marabolí, M., \& Peña-Neira, A. (2015). Effect of different aging techniques on the polysaccharide and phenolic composition and sensory characteristics of Syrah red wines fermented using different yeast strains. Food Chemistry, 179, 116-126.

Escribano-Bailón, M. T., \& Santos-Buelga, C. (2012). Anthocyanin copigmentation evaluation, mechanisms and implications for the colour of red wines. Current Organic Chemistry, 16(6), 715-723.

Gómez García-Carpintero, E., Gómez Gallego, M. A., Sánchez-Palomo, E., \& González Viñas, M. A. (2012). Impact of alternative technique to ageing using oak chips in alcoholic or in malolactic fermentation on volatile and sensory composition of red wines. Food Chemistry, 134(2), 851-863.

González-Manzano, S., Santos-Buelga, C., Pérez-Alonso, J. J., Rivas-Gonzalo, J. C., \& Escribano-Bailón, M. T. (2006). Characterization of the mean degree of polymerization of proanthocyanidins in red wines using liquid chromatography-mass spectrometry (LC-MS). Journal of Agricultural and Food Chemistry, 54(12), 4326-4332.

González-Neves, G., Gil, G., Barreiro, L., \& Favre, G. (2010). Pigment profile of red wines cv. Tannat made with alternative winemaking techniques. Journal of Food Composition and Analysis, 23(5), 447-454.

González-Sáiz, J. M., Esteban-Díez, I., Rodríguez-Tecedor, S., Pérez-del-Notario, N., Arenzana-Rámila, I., \& Pizarro, C. (2014). Modulation of the phenolic composition and colour of red wines subjected to accelerated ageing by controlling process variables. Food Chemistry, 165, 271-281.

Gordillo, B., Cejudo-Bastante, M. J., Rodríguez-Pulido, F. J., Jara-Palalcios, M. J., Ramirez-Pérez, P., González-Miret, M. L., \& Heredia, F. J. (2014). Impact of adding white pomace to red grapes on the phenolic composition and color stability of syrah wines from a warm climate. Journal of Agriculture and Food Chemistry, 62(12), 2663-2671.

Gordillo, B., Cejudo-Bastante, M. J., Rodríguez-Pulido, F. J., González-Miret, M. L., \& Heredia, F. J. (2013). Application of the differential colorimetry and polyphenolic profile to the evaluation of the chromatic quality of Tempranillo red wines elaborated in warm climate. Influence of the presence of oak wood chips during fermentation. Food Chemistry, 141(3), 2184-2190.

Gordillo, B., Rodríguez-Pulido, F. J., González-Miret, M. L., Quijada-Morín, N., RivasGonzalo, J. C., García-Estévez, I., ... Escribano-Bailón, M. T. (2015). Application of differential colorimetry to evaluate anthocyanin-flavonol-flavanol ternary copigmentation interactions in model solutions. Journal of Agriculture and Food Chemistry, 63(35), 7645-7653.

Heredia, F. J., Álvarez, C., González-Miret, M. L., Ramírez, A. (2004). CromaLab ${ }^{\circledR}$. Análisis de color. Sevilla, España: Registro General de la Propiedad Intelectual SE-1052-04.

Ivanova, V., Dörnyei, A., Márk, L, Vojnoski, B., Stafilov, T, Stefova, M., \& Kilár, F. (2011). Polyphenolic content of Vranec wines produced by different vinification conditions. Food Chemistry, 124(1), 316-325.

Jensen, J. S., Blachez, B., Egebo, M., \& Meyer, A. S. (2007). Rapid extraction of polyphenols from red grapes. Journal of Enology and Viticulture, 58(4), 451-461.

Monagas, M., Bartolomé, B., \& Gómez-Cordovés, C. (2005). Updated knowledge about the presence of phenolic compounds in wine. Critical Reviews in Food Science and Nutrition, 45(2), 85-118.

OIV (2012). International Codex of Oenological Practices. Usage of pieces of oak wood in winemaking (OENO 9/01) Edition.

Pérez-Lamela, C., García-Falcón, M. S., Simal-Gándara, J., Pérez-Lamela OrriolsFernández, I., et al. (2007). Influence of grape variety, vine system and enological treatments on the colour stability of young red wines. Food Chemistry, 101(2), 601-606.

Quijada-Morín, N., Hernández-Hierro, J. M., Rivas-Gonzalo, J. C. \& Escribano-Bailón, M. T. (2015). Extractability of low molecular mass flavanols and flavonols from red grape skins. Relationship to cell wall composition at different ripeness stages. Journal of Agricultural and Food Chemistry, 63(35), 7654-7662.

Sacchi, K. L., Bisson, L. F., \& Adams, D. O. (2005). A review of the effect of winemaking techniques on phenolic extraction in red wines. American Journal of Enology and Viticulture, 56(3), 197-206.

Soto Vázquez, E. Río Segade, S., \& Orriols Fernández, I. (2010). Effect of the winemaking technique on phenolic composition and chromatic characteristics in young red wines. European Food Research and Technology, 231(5), 789-802.

StatSoft Inc. (2007). STATISTICA. (Data analysis software system). Version 8. Tulsa, OK. <www.statsoft.com>.

Tao, Y., García, J. F., \& Sun, D. W. (2014). Advances in wine aging technologies for enhancing wine quality and accelerating wine aging process. Critical Reviews in Food Science and Nutrition, 54(6), 817-835.

Waterhouse, A. L. (2002). Wine phenolics. Annals of the New York Academy of Sciences, 957, 21-36.

Zimman, A., Joslin, W. S., Lyon, M. L., Meier, J., \& Waterhouse, A. L. (2002). Maceration variables affecting phenolic composition in commercial-scale cabernet sauvignon winemaking trials. American Journal of Enology and Viticulture, 53(2), 93-98. 